\title{
The Fighting Printers of Company E, Eleventh Kansas Volunteer Infantry
}

\author{
Author: Kim Allen Scott
}

"This is the final version of record of an article that originally appeared in Arkansas Historical Quarterly in September 1987."

Scott, Kim Allen. "The Fighting Printers of Company E, Eleventh Kansas Volunteer Infantry." Arkansas Historical Quarterly 46, no. 3(Autumn 1987): 261-81.

Made available through Montana State University's ScholarWorks scholarworks. montana.edu 


\title{
The Fighting Printers of Company E, Eleventh Kansas Volunteer Infantry
}

\author{
By KIM ALLEN SCOTT* \\ Special Collections, University of Arkansas Library \\ Fayetteville, Arkansas 72701
}

\begin{abstract}
$\mathrm{O}$
A LATE AfTERnoon in 1862, the footsore soldiers of Company E, Eleventh Kansas Volunteer Infantry, slowly made their way north along the Cane Hill road. The skimpy rations issued since dawn barely stayed the sharp pangs of hunger felt by the Yankee infantrymen as they trudged past scenes of yesterday's carnage. On the wooded Ozark slopes flanking the roadside, closely grouped corpses of men and horses lay strewn in mute testimony to the hotly-contested areas of the battle, and seemingly everywhere could be found broken fragments of weaponry and equipment which had been discarded during the running fight.

Captain Edmund G. Ross, the commander of Company E, probably tempered his discomfort by feeling the tender portion of his cheek where a Rebel Minie ball had grazed him, and reminded himself of his good fortune in escaping injury yesterday. A slight movement of his head would have sent the deadly missile directly into his brain, leaving his wife and children without the consolation of a final letter from him. ${ }^{1}$

As his unit entered the village of Cane Hill, Ross recalled the principal events of yesterday's fight. He thought of his own actions, and those of his command, feeling the urge to somehow preserve the story of the Eleventh Kansas and its sojourn in northwest Arkansas. "We will

*The author is manuscript processor for Special Collections, University of Arkansas Library, Fayetteville. He has owned and operated a letterpress printing office in Johnson, Arkansas, for the last five years and has published two other papers dealing with printing history. This paper won the Violet B. Gingles Award for 1987.

${ }^{1}$ Edmund G. Ross, letter to Fannie Lathrop Ross, November 30, 1862, Edmund G. Ross Collection (Kansas State Historical Society, Topeka, Kansas).
\end{abstract}


take great comfort in talking over these times when I get home again," he would later write his wife, "and the children, too, will take a deep interest in hearing descriptions of the country and scenes through which I passed." 2 Perhaps it was at this moment, when the Kansas soldiers filed slowly past the shops and homes of Cane Hill, that inclination and opportunity suddenly intersected as Captain Ross spotted the disheveled contents of a printing office scattered from a cabin doorway into the street. The former newspaperman hurriedly surveyed the pied type and battered press, making careful note of their location within the village. The possibility of preserving this moment in time literally lay before him.

On occasion in the study of history, a researcher comes across records left by a person acutely aware of his place in time. This pleasant circumstance of discovery happens all too rarely for the historian, probably because those busy making history are much too occupied to record events until long after the fact. In those infrequent cases where the record and activity were produced simultaneously, the document becomes a frozen moment in time, and like a photographic snapshot, it reveals a wealth of information for those willing to examine it closely. Such is the case of the Buck and Ball, a regimental newspaper published by the Eleventh Kansas Volunteer Infantry during December 1862 at Cane Hill, Arkansas.

Buck and Ball has hardly escaped the attentions of past historians. In his Life of Preston B. Plumb, William Connelley described the circumstances of the little newspaper's inception, and Bell Wiley has given the publication notice in his study of the average northern soldier in the Civil War. ${ }^{3}$ However, Connelley stressed his biographical subject's participation with the Buck and Ball to the detriment of those men who actually produced the sheet, and Wiley concerned himself with the publication only as an example of the northern soldiers' ingenuity. In neither account are the details of its production adequately chronicled, nor is the newspaper itself subjected to any external criticism. These oversights

2 Ibid.

${ }^{3}$ William E. Connelley, The Life of Preston B. Plumb (Chicago, 1913), 126-129; Bell I. Wiley, The Life of Billy Yank: The Common Soldier of the Union (New York, 1951), $179-183$. 
are unfortunate, for the information regarding Buck and Ball is quite extensive: more details are available on this single issue newspaper than any previous publication in Washington County, Arkansas. ${ }^{4}$ Another fact which has been overlooked is that one widely-circulated copy of the Buck and Ball in facsimile reprints and microfilm is actually a carefully produced forgery. Evidence of the publication's reprinting years after the original, along with the proper recognition of the actual printers of the Buck and Ball, will be demonstrated in the course of this paper.

The real story of the Buck and Ball begins in Topeka, Kansas, August 11, 1856, the day newspaperman Edmund G. Ross arrived to make his fortune in the new territory. ${ }^{5}$ Ross was born in Ashland, Ohio, in 1826 and began learning the printer's trade at the age of eleven in the office of the Huron Ohio Advertiser. He spent his early years working in a number of newspaper plants, gaining a competency in all phases of production. He married Fannie Lathrop of Sandusky in 1848, and the couple moved two years later to Wisconsin where Edmund's brother got him a position at the Milwaukee Free Democrat. ${ }^{6}$

Events transpiring in Kansas Territory during the mid-1850s would change the life of Edmund Ross. Kansas was then the scene of a bitter struggle between pro- and anti-slavery zealots determined to gain statehood for the territory with a constitution guaranteeing their respective positions on human servitude. Ross, an ardent abolitionist, joined a company of like-minded settlers from Wisconsin emigrating to Kansas in 1856. His first years in the new land were spent as a volunteer in the Free State army, a militia organization determined to prevent Kansas from becoming a slave state. Later he settled in Topeka where he chose to do battle against slavery with the pen rather than the sword as a newspaper editor.

In 1859 Ross established a newspaper called the Kansas State Record. Having himself graduated from the typecase to the editor's chair, the

\footnotetext{
${ }^{4} \mathrm{Kim}$ A. Scott, "Window on the Frontier: The Early Newspapers of Washington County, Arkansas, 1840-1862" (unpublished M. A. thesis, University of Arkansas, 1986).

${ }^{5}$ Richard W. Robbins, "The Life of Senator Edmund G. Ross of Kansas," Kansas Historical Quarterly, XXXIII (Spring 1967), 95.

${ }^{6}$ Ibid., 93. Most of Robbins's material appears to be drawn from Edward Bumgardner, The Life of Edmund G. Ross: The Man Whose Vote Saved a President (Kansas City, Kan., 1949).
} 
new proprietor became a fair-handed and popular employer, and the Record office soon flourished under the watchful eyes of a number of dedicated craftsmen. Nathan P. Gregg and John Howard Kitts served the office efficiently as typesetters, while a lad named James Conwell played the "devil" for the Record, performing all the menial tasks delegated to a neophyte just learning the trade. When the time came for James to learn typesetting himself, he introduced a companion, Henry C. Lindsey, to the boss for consideration. Ross took a liking to young Lindsey, but the boy's habitual cursing offended the editor and he only offered Lindsey the job on condition that he cease his foul utterances. ${ }^{7}$

The staff of the Record office would probably have cheerfully prospered together had not war interrupted. In April 1861 disgruntled southerners put the question of settling their differences with the federal government to the gunpowder test and the nation sank into four miserable years of civil war. At first Ross and his printers followed the course of the conflict through exchange papers and telegraph dispatches, but by 1862 they found themselves caught up in the fray at a much more personal level.

Kansas, itself admitted to the Union as a free state in January 1861, responded to President Lincoln's call for 300,000 more volunteers in 1862 with grim determination. The new state had already furnished ten regiments for the cause, but an ambitious recruiting drive began to convince still more husbands, sons, and fathers, that their country's hour of need was at hand. Thomas H. Ewing, chief justice of the Kansas Supreme Court, received authorization to raise a regiment of infantry to be designated the Eleventh Kansas Volunteers. Edmund Ross decided to join the conflict and himself received permission to raise a company for the new regiment. Among the first to sign up with him were the printers from his own office, including Henry Lindsey, who was accepted only as a drummer boy due to his age. ${ }^{8}$ This recruitment "en masse" could be interpreted as a testimonial to the respect and popularity Ross enjoyed from his printers, but the spirit of the moment must have accounted for some of the men's motivation. John Howard Kitts described his reaction

\footnotetext{
${ }^{7}$ Clad Hamilton, "A Colonel of Kansas," Collections of the Kansas State Historical Society, XII (1911-1912), 283.

${ }^{8}$ Ibid.
} 
to a recruiting rally held in Americus, Kansas, on August 23, 1862, in language that helps illustrate the prevailing mood:

Speeches made by Chief Justice Ewing - who was recruiting the Eleventh Kansas regiment of volunteers - P. B. Plumb and others. After the speaking opportunity was given to all who wished to go for a "bold soldier boy" in the defense of this good old Union, to protect that "good old flag," and wipe out treason from the best government the sun ever shone on. ${ }^{9}$

The new regiment spent most of the month of September 1862 in a camp near Fort Leavenworth, organizing themselves into companies and electing officers. The men recruited by Edmund Ross, designated as Company E, promptly elected the former editor as their captain and Nathan P. Gregg as second lieutenant. The soldiers cast their ballots with an eye on military experience as well as popularity, for both Ross and Gregg had previously served in military organizations. ${ }^{10}$ Another newspaperman, Preston B. Plumb of the Emporia Kanzas News, won the confidence of his men by first accepting the captaincy of Company C, and later, on September 25, gaining a promotion to the rank of major. ${ }^{11}$

During the weeks of initial organization, the printers in Company $\mathrm{E}$ drilled and trained without the benefit of weapons. A little more than a month had passed between the first call for troops and the regiment's final mustering, leaving no time to adequately equip the recruits. By the time they were called to the front in early October, the Eleventh was desperate for armament. The quartermaster at Fort Leavenworth managed to find a supply of 1818 Prussian model smoothbore muskets, and Colonel Ewing ordered the antique guns issued to his men. The muskets were huge, .72 calibre pieces with brass finished barrels, most efficiently used as giant shotguns when firing a load of one large lead ball and several smaller ones. Regardless of their effectiveness, the near eleven pound weight of the guns would prove to be a heavy burden on the shoulders of Ross's men during the course of their first campaign.

\footnotetext{
9John Howard Kitts, "The Civil War Diary of John Howard Kitts," ibid., XIV (19151918), 318-319.

${ }^{10}$ Kansas Adjutant General's Office, Military History of Kansas Regiments for the Suppression of the Great Rebellion (Leavenworth, Kan., 1870), 324.

${ }^{11}$ Connelley, Preston B. Plumb, 107.
} 
On the morning of October 4, 1862, the Eleventh Kansas marched out from Fort Leavenworth to join Brigadier General James G. Blunt's division of the Army of the Frontier operating in Missouri. Southwest Missouri, northwest Arkansas, and the eastern Indian Territory had all been the scene of contention between northern and southern armies ever since the summer of 1861. In early March 1862 the main Confederate army of the Trans-Mississippi District under Major General Earle Van Dorn was defeated after three bloody days of fighting at Pea Ridge, Arkansas. The southern army broke up after the fight and many of its units were transferred to theaters east of the Mississippi, but smaller groups remained behind to threaten the western border throughout the summer of 1862. Command of the First Corps of the Trans-Mississippi Army next fell to Major General Thomas C. Hindman on August 24, 1862. Hindman, an energetic and tireless organizer, raised and equipped a sizeable army during his tenure of command and determined to support southern units operating in the Ozark country.

On October 4, the day the Eleventh Kansas set out to join him, General Blunt's division managed to dislodge an advance contingent of Hindman's army at the town of Newtonia, Missouri. Parts of the southern forces fled toward the Indian Territory, while others retreated south, past the town of Fayetteville, Arkansas, to regroup in the Arkansas River valley beyond the rugged Boston Mountains. Blunt, anxious to pursue the enemy, set the stage for yet another campaign in northwest Arkansas.

While the federals attempted to follow up their victory at Newtonia, the Eleventh Kansas hurried southward. The unbloodied printers of Company E, more accustomed to a sedentary lifestyle than recruits from more strenuous occupations, were unused to the pace of forced marches and adapted themselves as best they could. Captain Ross suffered particularly from the march because, in spite of the rheumatic pains in his knees, he determined to set an example for his men. ${ }^{12}$ Private Kitts recorded his solution to fatigue in his diary on October 5: "I felt so sore and tired

\footnotetext{
12 Edmund G. Ross, letter to Fannie Lathrop Ross, December 29, 1862, Edmund G. Ross Collection. In this later correspondence, Ross recalled the hardships of the previous marches and reported to his wife that presently his pain was so bad that he could not get up in the morning.
} 
that, it being my time to go on guard, I hired a soldier belonging to the regular service, who was going with us to Fort Scott, to stand my guard for 75 cents. Distance 15 miles." ${ }^{13}$ The heavy muskets were a constant drain on the soldiers' stamina, so much so that at one point before arriving at Fort Scott, Kansas, wagons were brought up to carry the guns the rest of the distance to the post, allowing the men to proceed unencumbered. ${ }^{14}$

On October 13, the Eleventh Kansas crossed the Missouri state line and paused for an afternoon of target practice. None of the printers in Company $\mathrm{E}$, or in the entire regiment for that matter, had ever fired their bulky weapons before, and it is somewhat surprising that Colonel Ewing allowed the expenditure of ammunition at this point on the march. ${ }^{15}$ It took an enormous amount of powder to fire the "buck and ball" loads, and since the muskets had no rifling, their accuracy was deplorable. "We did not do the best marksmanship in the world," recorded Private Kitts in a hopeful understatement, "but we expect to better it after a few trials." ${ }^{16}$ Colonel Ewing, in a somewhat lame attempt to encourage his regiment after the dismal practice session, stressed the power and force of the guns by calling them "light artillery."

The Eleventh Kansas joined with the first division of the Army of the Frontier at Pea Ridge, Arkansas, on October 19, 1862. General Blunt's plans to carry the offensive to the Confederates did not allow the Kansas soldiers much time to rest. Within two days the regiment was ordered to advance west toward the Indian Territory and engage a Rebel force at Fort Wayne. Another forced march did not allow the printers of Company $E$ to see any action, though. When scouts reported the enemy camped just a few miles west of Maysville, Arkansas, the Second Kansas Cavalry rushed forward with artillery support and routed the Confederates just as the exhausted infantrymen arrived on the field.

"Hurry up and wait!" has been a long standing soldier's complaint

${ }^{13}$ Kitts, "Civil War Diary," 319.

14 lbid., 320.

${ }^{15}$ Wiley, Billy Yank, 50-51. "Practice with live ammunition was a rarity. . . Perhaps one of the reasons for neglect of target practice early in the war was the notorious inaccuracy of the antiquated muskets with which many soldiers were issued at the time."

${ }^{16}$ Kitts, "Civil War Diary," 325; see also Buck and Ball, December 7-15, 1862, p. 1. 
regarding military movements, and the men in Captain Ross's company could have easily applied it to their own situation. After a journey of nearly 325 miles, covered in marches averaging over 18 miles a day, they found themselves in an abundant agricultural region with no enemy to fight and little to do other than forage for supplies. At this last, Company E proved itself to be all too efficient.

On November 4 Captain Ross and Company E were sent out from the Eleventh's main camp six miles south of Bentonville on a foraging expedition to Brown's Mill, a grist mill on the Osage Creek just west of Elm Springs, Arkansas. Convinced the owner was a southern sympathizer, the Yankees had no compunction over robbing him of everything he had. "The old cuss raved and tore around when we took his stuff," sniffed Private Kitts after relieving the "rank secesh" of some vegetables and livestock. ${ }^{17}$ Ross's men also destroyed a tannery at Cincinnati and pillaged other settlers during the expedition, using their own judgment to determine which people would be issued scrip for confiscated goods, and those whose property would simply be taken or destroyed.

The necessity of war forced the Federals into this organized vandalism, but frustration regarding their lack of activity may account for their zeal in carrying out their orders. The Kansas soldiers had been in the army nearly two months without firing a shot in anger, and their only casualty during the march into Arkansas occurred when a private in Company C accidentally shot himself with his own musket while on guard. ${ }^{18}$ During the weeks following the Brown's Mill expedition, Captain Ross and his men spent their time foraging or just lying in camp, excited periodically by false reports of Confederate troop movements and sporadic sniping incidents involving partisan rangers. The tension resulting from the dull routine of camp life interrupted by real and imagined attacks from an unseen enemy must have been comparable to the stress experienced by some troops during the Vietnam conflict who also faced a phantom adversary. Like their modern counterparts, the soldiers in Company E sometimes reacted to their situation by dealing harshly with civilians they felt were supporting the enemy.

By end of the month scouts reported a large Confederate force occupy-

${ }^{17}$ Kitts, "Civil War Diary," 325.

18 Ibid., 329. 
ing the country around Cane Hill, Arkansas, a hamlet about thirty miles south of Blunt's main camp. The general moved swiftly by ordering his men on a rapid march without supply wagons to dislodge the enemy. On November 27, 1862, the Eleventh Kansas moved out to receive their baptism of fire with elements of the First and Third Union Indian Regiments, the Second Kansas Cavalry, and artillery support.

A twenty-five mile forced march brought the Yankees within fifteen miles of their objective by midnight. Exhausted and hungry, the Eleventh Kansas made a hasty camp to sleep as best they could on the field, but a 5:00 a.m. reveille the next day found the Jayhawkers again called to their feet ready to march. General Blunt managed to find an obscure country road leading directly south toward Cane Hill and he directed his advance guard to follow this route rather than the more easily travelled State Line-Cincinnati road. By this maneuver his soldiers were able to approach within a half mile of the Rebels without detection because the Confederate pickets mostly concentrated their attention on the Cincinnati road to the west, and the Fayetteville road to the east.

The town of Cane Hill, situated along the Jordan Creek, is flanked on the west by a gently sloping ridge and on the east by mountains ending in steep bluffs just beyond the creek. On College Hill, the ridge to the west, Brigadier General John S. Marmaduke, the Confederate field commander of Hindman's forces, had positioned an artillery piece to protect the approach from Cincinnati. On the steep bluffs to the east of the Jordan, another gun was placed to guard the Fayetteville road. When the first elements of Blunt's command arrived on the scene the guns were wheeled about in order to stage a deadly crossfire against the Federals. ${ }^{19}$

Blunt hastened his cavalry and artillery units forward and personally deployed them after ascertaining the enemy's position. He then sent back word to the slower infantry regiments to march at the double quick in order to support their comrades. The fierce artillery duel which opened the battle of Cane Hill began about 10:00 a.m., a full hour before the Eleventh Kansas arrived on the field. ${ }^{20}$

${ }^{19}$ U. S. War Department, The War of the Rebellion: A Compilation of the Official Records of the Union and Confederate Armies (70 vols. in 128, Washington, 1880-1901), Ser. I, Vol. XXII, pt. 1, p. 56; cited hereinafter as $O R$.

${ }^{20}$ Ibid., 41-59. 
Captain Ross and his men, eager for the fight and perhaps a bit anxious that the enemy would again retreat before they would get a chance to participate, took their positions at the base of College Hill while the Second Indiana Battery forced the first line of Confederates to withdraw. Soon afterwards, the rest of Blunt's infantry arrived and engaged in the desperate business of driving Marmaduke's men south through the town and then southeast over the broken, treacherous terrain. The Confederates stopped periodically to cover their retreat, forming a firing line behind their comrades and then withdrawing after loosening a murderous volley at the pursuing Federals.

The battle became a running fight, southeast to the Boston Mountains which separate the Cane Hill region from the Arkansas River valley. None of the men in Company $\mathrm{E}$ were killed, but there were many close calls during the pursuit. One soldier had a button shot off his coat, another had the unsettling experience of being struck square in the breast by a spent bullet. Captain Ross himself saw a tree limb over his head split by a cannon ball in addition to the bullet that whispered past his cheek. ${ }^{21}$

On and on Company E chased the foe, blasting volleys of buck and ball when the opportunity arose, and otherwise running full speed through the woods as the Rebels gave ground. After a life-and-death chase of a dozen miles over unbelieveably rough country, the Kansas infantrymen began to fall out, not from wounds or casualties, but from the sheer exertion of running so far with their heavy muskets. By the time nightfall arrived and a halt was ordered, Captain Ross's command had covered at least thirty-four miles since reveille. Not all of the men could keep up the demanding pace though, for when Ross called the roll that night only twenty-six of Company E's sixty-seven men answered. ${ }^{22}$

The soldiers simply fell down wherever they happened to have stopped, utterly drained from the day's efforts and unable to move. They were without food or blankets, having left them behind at their morning's camp, and while some men had enough energy to build fires, others, like Captain Henry A. Palmer of Company A, resorted to burying themselves in piles of leaves, desperately attempting to warm them-

\footnotetext{
${ }^{21}$ Edmund G. Ross, letter to Fannie Lathrop Ross, November 30, 1862, Edmund G. Ross Collection.

22 Ibid.
} 
selves during the chilly November night. ${ }^{23}$

The next morning, November 29, blankets, overcoats, and food arrived and Company $\mathrm{E}$ was ordered to the rear to bivouac at Cane Hill. It was on this march that Captain Ross and his men made their remarkable discovery. "Went through the town and found an old printing office that had been used to publish the Cherokee Messenger," wrote Private Kitts that evening, adding somewhat lamentedly, "It had been thrown into 'pi'." 24

Just exactly how a printing office came to be located at Cane Hill has remained a puzzle to historians. Although Cane Hill College, a Presbyterian school established at the town in 1834, may have had a use for a printing office, it is unlikely the one found by Captain Ross belonged to it. There are no extant imprints from Cane Hill College during the entire period from its founding to 1862 other than a catalog produced for the 1858-1859 session, and that specimen came from the Fort Smith office of Wheeler and Sparks. ${ }^{25}$ If the college had its own press it does not follow that they would send such a vital piece of work to a distant printer.

Captain Ross may have found a newspaper office, but the location of a newspaper at Cane Hill before the Civil War has never been documented. The presence of an active newspaper in the town would have surely attracted the attention of journals in Fayetteville and Fort Smith, but these sources are silent on the matter. Indeed, the Fayetteville Arkansian, published at that place from 1859 to 1862 , regularly reported on activities at Cane Hill College that would surely have noted an exchange newspaper there. One theory advanced by James P. Neal states that William Quesenbury, a Fayetteville editor, moved his press to Cane Hill for safekeeping after the outbreak of hostilities. ${ }^{26}$ The story might be

\footnotetext{
${ }^{23}$ Henry E. Palmer, "An Outing in Arkansas, or, Forty Days and a Week in the Wilderness," Civil War Sketches and Incidents (Papers read by Companions of the Commandery of the State of Nebraska, Military Order of the Loyal Legion of the United States, Omaha, 1902), Vol. I, 220.

${ }^{24}$ Kitts, "Civil War Diary," 327.

${ }^{25}$ Cane Hill College Catalog (Fort Smith, Ark., 1858), in Special Collections (University of Arkansas Library, Fayetteville, Arkansas).

${ }^{26}$ Walter J. Lemke, "Buck and Ball," Washington County Historical Society Flashback, XII (December 1962), 30.
} 
plausible were it not for the fact that Quesenbury owned no press in 1862, having sold the one he used to publish the South-West Independent to Wheeler and Sparks in $1858 .^{27}$

Private Kitts's diary observation that the mysterious press had been used to publish the Cherokee Messenger was probably mere speculation based on conversation with some of the Federal Indian soldiers who were familiar with that publication and recognized Cherokee characters amidst the pied type. Kitts's contemporary guess led historian William E. Connelley to surmise the press had come from the Jones Baptist Mission, an outpost located a few miles west of Cincinnati in the Indian Territory. After detailing an elaborate theory of the press's removal by the Reverend Jones to Cane Hill for settlement of a debt, Connelley's Life of Preston B. Plumb further described the mission's printing operation being manned by none other than Sequoyah himself! ${ }^{28}$ Connelley's version of how the press got to Cane Hill has been thoroughly discredited by an unpublished paper by A. D. Lester which presents a logical case for the destruction of the Jones Mission press long before the Cane Hill fight. ${ }^{29}$

But the Jones Mission was not the only Cherokee printing office near Cane Hill prior to the Civil War. The Park Hill Press, operated by Abijah and Hanna Worcester Hicks near the Cherokee capital of Tahlequah, was no more than forty miles west on a main road from Cane Hill. After the murder of her husband in early 1862, Mrs. Hicks abandoned her printing office to seek protection from bushwhackers at Fort Gibson. On September 10, 1862, she returned to Park Hill for a brief visit. "Today I went to the printing office," she wrote in her diary, "I did not know before how completely it had been cleaned out: the press, types, papers, etc., all carried off or destroyed." ${ }^{30}$ It is important to note that Mrs. Hicks

${ }^{27}$ Scott, "Window on the Frontier," 46.

${ }^{28}$ Connelley, Preston B. Plumb, 126-127.

${ }^{29}$ A. D. Lester, "Evan Jones, Baptist Pastor and Missionary, 1821-1872: A Man that Truly Endured Hardness as a Good Soldier of Jesus Christ," Westville, Oklahoma, 1970, pp. 54-64; a microfilm copy of the bound typescript is in the University of Arkansas Library at Fayetteville.

${ }^{30}$ Muriel Wright, "Notes on the Life of Mrs. Hanna Worcester Hicks Hitchcock and the Park Hill Press," Oklahoma Historical Society Chronicles of Oklahoma, XIX (December 1941), 351. 
did not itemize the destruction of her office and clearly said that some of the equipment had been removed rather than wrecked. If we consider the disappearance of a press and Cherokee type in September 1862, along with the sudden appearance of the same in November 1862 at a point forty miles away, it is reasonable to conclude that the press discovered by Captain Ross and the printers of Company E was the same one operated by Mrs. Hicks at Park Hill.

Regardless of how the printing equipment came to be at Cane Hill, its presence in the town proved to be an irresistible attraction to some of the men in Company E. Faced with the prospect of another lengthy, boring bivouac, Captain Ross felt the printer's ink in his blood stirring with anticipation of again practicing his civilian trade. After setting up a camp for his men atop College Hill, Ross hurried to report his find to Major Plumb. Printing is an ancient trade with traditions that find their roots in the Renaissance. Knowledge of the craft tends to blur the distinctions of class differences between practitioners, and military rank would prove no exception to this trait. Major Plumb became as excited over the discovery as Captain Ross, and the two officers sought out Private Kitts before walking back down the hill to the town. Together, the three printers would assess the contents of the office and determine its potential use. $^{31}$

The broken press lay within a small cabin surrounded by thousands of spilled pieces of type. At least three different fonts of tiny, eight point type could be found amidst the scattered lead characters, along with a few random samples of larger display faces and Cherokee symbols, all of which were tumbled into hopeless disarray on the cabin floor and out into the street beyond. After sifting through a handful of the leaden slivers, Kitts announced that he believed he could sort them out, and Ross found a couple of cases that could be patched up enough to receive the separated type. Major Plumb, after determining that the press might be serviceable if assembled properly, gave his approval for the men to produce a regimental newspaper and began planning an essay or two for publication. ${ }^{32}$

\footnotetext{
${ }^{31}$ Kitts, "Civil War Diary," 328.

32 Preston B. Plumb Collection, Scrapbook 3, p. 8 (Kansas State Historical Society, Topeka, Kansas).
} 
"I found a printing office in the town today," Ross excitedly wrote his wife that evening, "I have been engaged in setting it up. We will get out a paper in a few days and I will send you a few copies." ${ }^{33}$ For the next five days Ross and his printers worked at fulfilling his promise, slowly separating the type into sorts and setting up columns when the supply proved sufficient. Aside from John Howard Kitts, the names of the soldiers who helped have not been recorded in the Buck and Ball, but one may safely assume the former employees at the Kansas State Record, including Nathan P. Gregg, James Conwell, and Henry C. Lindsey were all involved with the project. In an undated newspaper clipping produced during his post-war senatorial career, Preston Plumb claimed that Captain Samuel J. Crawford of the Second Kansas Cavalry also assisted with the printing at Cane Hill, but in his own memoirs, Crawford never mentioned any involvement. ${ }^{34}$

The printers made slow progress. In addition to the difficulties in separating English characters from the Cherokee, and the mechanical tinkering required to repair the press, the soldiers were called away from their work from time to time when rumors of enemy troop movements stirred the camp. The remarkable dedication of the printers in the face of such adverse conditions is demonstrated by Private Kitts's diary entry for December 5. On that day he scribbled almost nonchalantly about working all night in the printing office after spending the day on a fruitless march of four miles in full pack against the Confederates. ${ }^{\mathbf{3 5}}$

The supply of type available to the printers of Company E determined both the content and appearance of their newspaper. Large display characters were scarce, probably because other soldiers had ransacked the office prior to Ross's arrival and carried off pieces as souvenirs. When the name Buck and Ball was chosen for the masthead of the newspaper, the unfortunate compositors still found themselves short one letter and had to whittle a replacement from a piece of wood. ${ }^{36}$ In the news columns the dearth of proper font sorts forced Ross's crew into incorporating a

\footnotetext{
${ }^{33}$ Edmund G. Ross, letter to Fannie Lathrop Ross, November 30, 1862, Edmund G. Ross Collection.

34 Preston B. Plumb Collection, Scrapbook 3, p. 8; Samuel J. Crawford, Kansas in the Sixties (Chicago, 1911), 68-79.

${ }^{35}$ Kitts, "Civil War Diary," 126.

${ }^{36}$ Preston B. Plumb Collection, Scrapbook 3, p. 8.
} 
bewildering mixture of characters - small capitals, italics, and roman faces - into the individual lines of set type. As long as their work proved legible, the printers of Company $\mathrm{E}$ felt comfortable with the mongrelized matter they prepared for printing.

Six columns of type describing the march of the Eleventh Kansas from Fort Leavenworth to Cane Hill, and essays dealing with the issue of civilian property destruction written by Major Plumb, were finally locked into the chase, ready for printing. Although the crew found a good supply of ink, enough paper for their needs proved to be a bit more difficult to secure. By begging, borrowing, scrounging, and bartering, they came into possession of nearly three reams of lined army foolscap paper and began the presswork on the first side of the Buck and Ball.

As he pulled the first sheet from the press to admire his colleagues' handiwork, Private Kitts smiled at the slogan he had personally composed for the masthead: "Calibre 72: Gives the Rebels H - - 1!" Remembering the enemy running pell-mell through the woods after receiving a volley from the Eleventh's "light artillery" had inspired Kitts, and since the paper's title described the Eleventh's ammunition, he felt it only proper to elaborate. How many copies were struck off with Kitts's mildly vulgar message is not known, but it could not have been very many out of the total run of 1,500. ${ }^{37}$ Edmund Ross's distaste for cursing has already been described, and we can safely assume the captain ordered the press stopped and a substitute slogan locked into the masthead as soon as he found out what Kitts had been up to. "Kansas is Pisin to the Hull on 'em." read the replacement, and the balance of the issue printed bore that slogan.

Kitts's blunder had much more far reaching effects than he ever could have imagined. Years later, long after the war's end, someone having possession of a Buck and Ball with Kitts's original imprint painstaking attempted to duplicate it. Why this forgery took place can only

\footnotetext{
${ }^{37}$ Only one original copy of the "Calibre 72" edition of Buck and Ball has survived, compared with three "Kansas is Pisin" versions, all of which are held by the Kansas State Historical Society in Topeka, Kansas. The original "Calibre 72" issue was donated in 1881 by $\mathrm{O}$. H. Macauley and has an accession number of 5165 . The three "Kansas is Pisin" issues bear numbers 11590,1922 , and 47752 . It is interesting to note that the counterfeit Buck and Ball is the only issue in the collection that does not bear an accession number.
} 
be speculated, but politics may have played a part. Major Preston B. Plumb and Captain Edmund G. Ross both became United States senators from Kansas after the Civil War, while the Eleventh's lieutenant colonel, Thoms Moonlight, became governor of Wyoming. Samuel J. Crawford, the officer from the Second Kansas Cavalry whom Plumb claimed helped with the paper, was also active in Kansas politics and became that state's governor. Any one of these men could have benefitted from publicity extra copies of the Buck and Ball might have generated.

The evidence of the forgery is clear on comparison of the two versions of the paper held by the Kansas State Historical Society in Topeka (Appendixes A and B). The original "Calibre 72" issue is printed on the same lined white foolscap as all the other extant "Kansas is Pisin" copies, and both have the same slab-serif display characters spelling "Buck and Ball." The counterfeit is printed on wood pulp paper and has sans-serif characters forming the title. Although the column width is the same between the two papers, the forger was unable to match the exact type face used in the original, resulting in a difference between the number of words fitted to each individual line. It is interesting to note that the spurious copy bears evidence of a careful effort to duplicate the same mixture of small capitals, italics and roman characters found in the original, leading one to speculate that the printing may have been done after Senator Plumb's newspaper interview wherein he described the mongrelized type used in the Buck and Ball. ${ }^{38}$

It can be argued that the exigencies of the front forced the printers of Company $\mathrm{E}$ to use a wide variety of paper stocks and display types, but sans-serif display characters were rare items in 1862 printing offices, and wood pulp paper practically nonexistent. Even if they had found such paper and type, why would Ross's men reset the entire newspaper for a second printing? It would have taken almost as much time to rearrange each line of type to match the contents of the counterfeit Buck and Ball as it did to set them up in the first place.

It is important to note that the sans-serif issue of the Buck and Ball is a forgery because it is the copy which has been most widely distributed for scholarly research. Since it is sharper and more legible than the

${ }^{38}$ Preston B. Plumb Collection, Scrapbook 3, p. 8. 


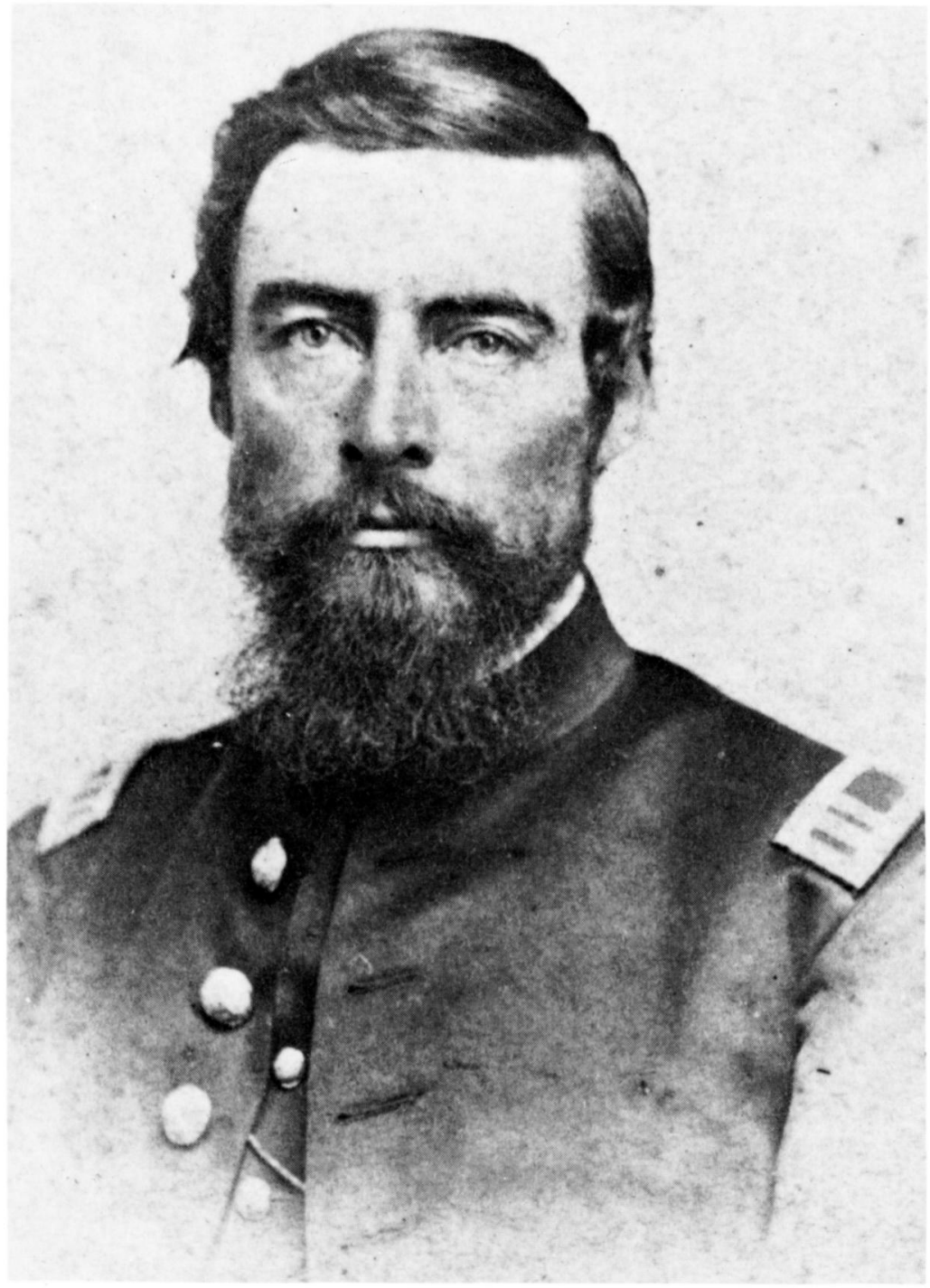

CAPTAIN EDMUND G. ROSS

Company E, Eleventh Kansas Volunteers, ca. 1862

COURTESY KANSAS STATE HISTORICAL SOCIETY, TOPEKA, KANSAS 


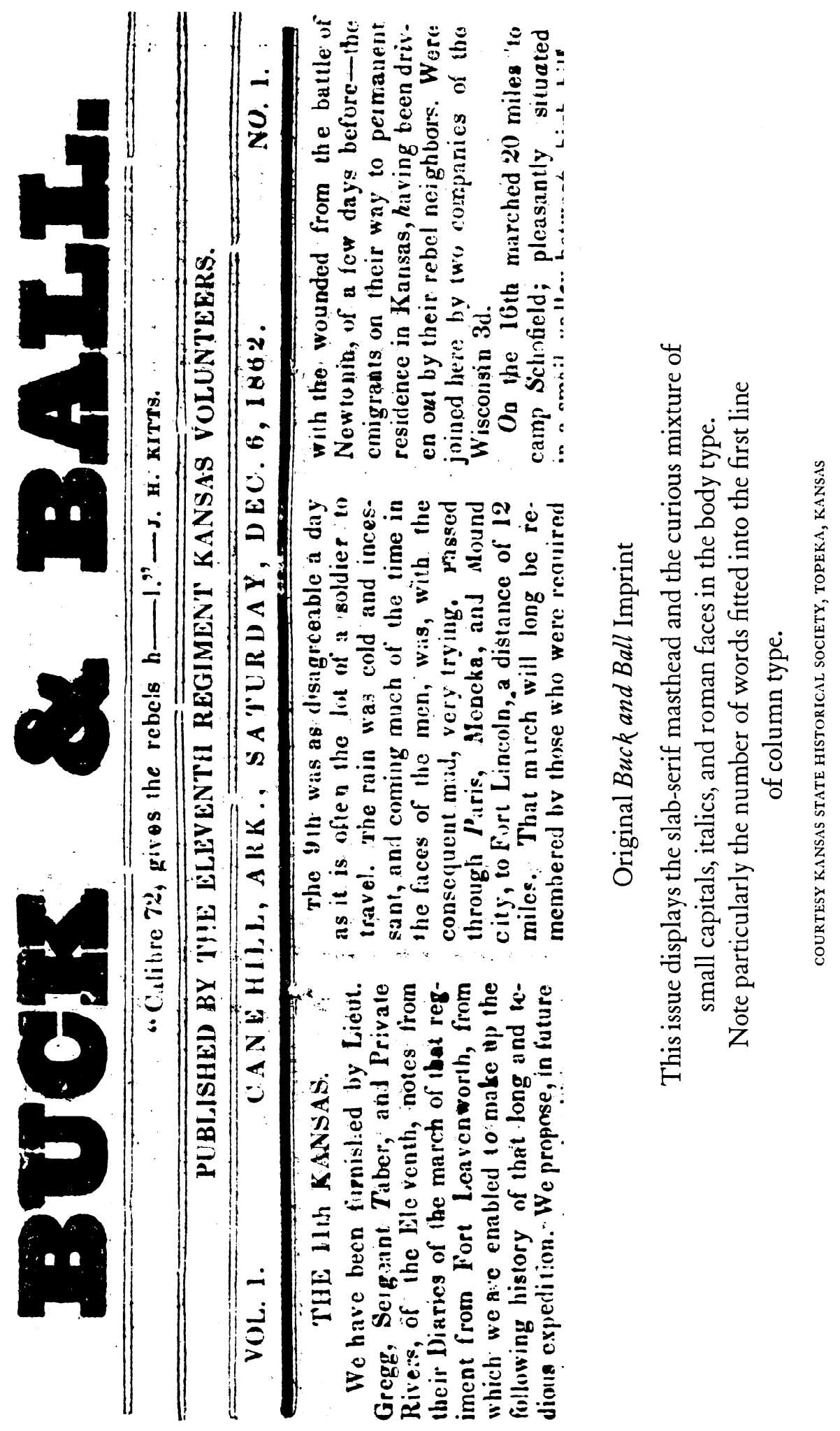




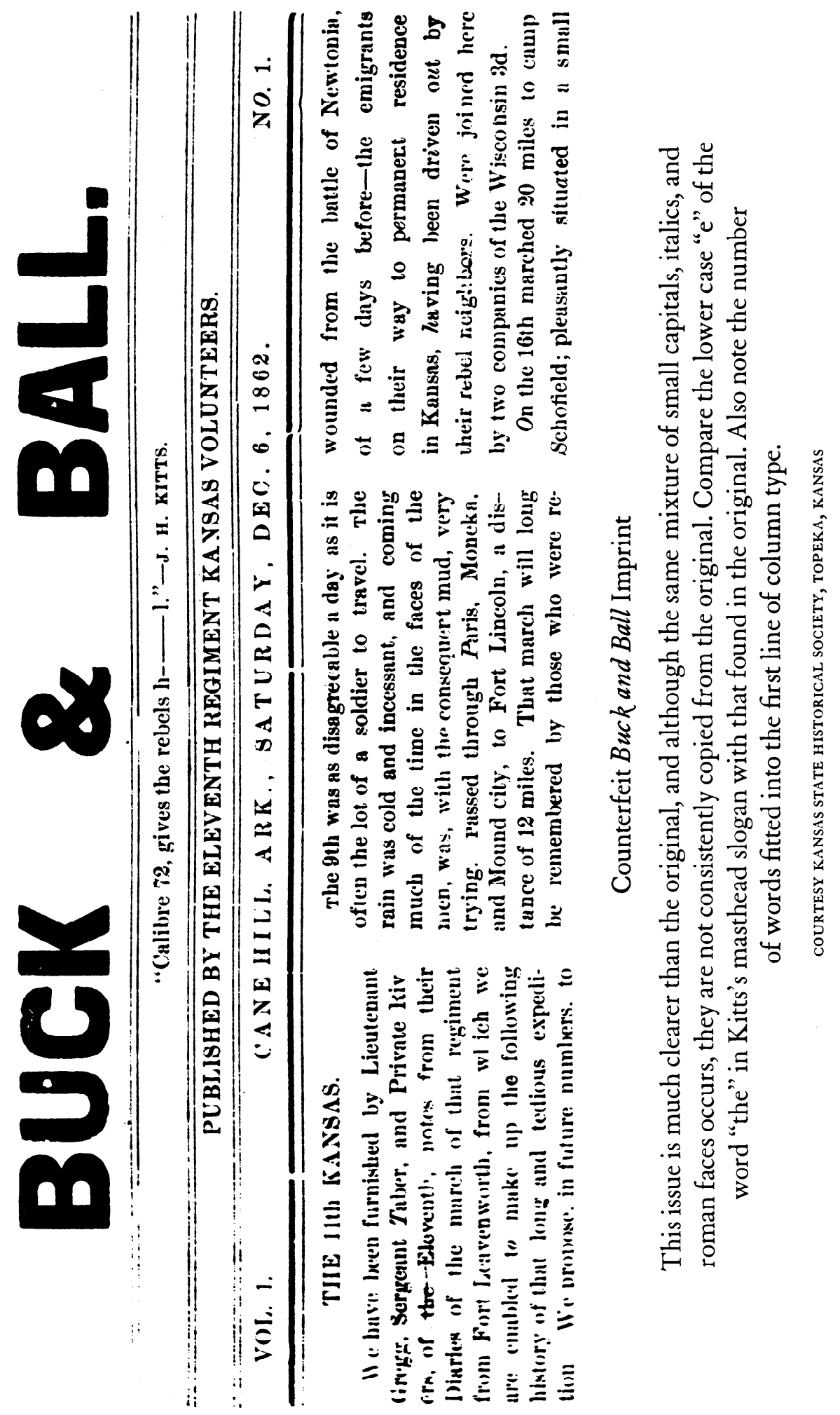


original, the counterfeit copy has been the one chosen for microfilming and copying over the years in a variety of publications. ${ }^{39}$ Before presenting facsimiles to the public, historians need to be aware if documents provided for research are genuine or not.

On the morning of December 6, 1862, after admiring the printing on the first side of their newspaper, Captain Ross and his printers prepared to distribute the type back into the cases in anticipation of setting up the columns for the inside pages. Unfortunately, the war they attempted to describe would not wait, and by the afternoon, Major Plumb ordered Company $E$ to break camp and move south to join with troops engaging the enemy at Reed's Mountain. Plumb's contingent, under order to hold their position at all peril, was still at Reed's Mountain on the morning of December 7, even though the major knew the rest of the Federals were evacuating Cane Hill in preparation for what would become the battle of Prairie Grove. A staff officer finally arrived on the scene and ordered the Kansas soldiers to rejoin their regiment near Rhea's Mills. When he marched his unit back through Cane Hill, Plumb stopped for a moment to gather up the half-printed sheets of the Buck and Ball and threw them into the back of a passing ambulance wagon. For all they knew, the men in Company $\mathrm{E}$ probably figured their printing experiment in Arkansas was over for good.

A satisfactory account of the battle of Prairie Grove has yet to be written. So many personal narratives, diaries, and letters describing the fight are available that it is surprising no one has published a book length study at this late date. Such a task is clearly beyond the scope of this paper, even though the printers of Company E played a significant role in the battle, and a brief summary of their exploits will have to suffice.

Captain Ross and his men were detailed to support the Second Indiana Battery close to the center of the Confederate line. The open field in which the battery was positioned offered little cover for the Yankees as wave after wave of Confederate infantry attacked them. Although

${ }^{39}$ Lemke, "Buck and Ball," 30-31; Walter J. Lemke, Battle of Prairie Grove Arkansas, December 7, 1862, published by the Washington County Historical Society, Fayetteville, Arkansas, as a souvenir of the visit to the battlefield by the Civil War Round Table of Chicago, April 21, 1967, pp. 3-4; "Miscellaneous Arkansas Newspapers," microfilm 1260 (University of Arkansas Library, Fayetteville, Arkansas). 
they endured some of the hottest fire on the field, Company E lost only one man killed, probably because their wing commander, Lieutenant Colonel Thomas Moonlight, had the good sense to order his men to lay flat on the ground during the enemy's charges. Throughout the ordeal the printers performed their duty with conspicuous gallantry and earned favorable mention in a number of official reports of the battle. ${ }^{40}$

Following the fight at Prairie Grove, Company E, along with the rest of the Eleventh Kansas, returned to their old camp at Cane Hill. Thanks to Major Plumb's foresight, and the fact that no other passing troops had ransacked the printing office during their absence, Ross's men were able to resume their publishing efforts. The half-printed sheets were retrieved from the ambulance and the type from the first side's printing was distributed back into the cases. Then, Private Kitts and the other compositors began to set up six more columns for the inside of Buck and Ball. The subject matter easily suggested itself and the story of the battle of Prairie Grove slowly took shape. A brief account of the fight at Cane Hill on November 28, along with the text of Confederate General Hindman's address to his troops (advising them, among other things, to aim specifically at Yankee officers), just about filled the remaining space on the page. Only a little room was left for an explanation of the discrepancy of the printing dates from one side to the other, and a somewhat boastful elaboration of the newspaper's name: "Buck and Ball, when applied to musketry, means death to Rebels; when applied to newspapers means the enlightenment of the Rebel mind to the reception of the truths of Freedom." ${ }^{41}$ Some of the buildings at Cane Hill had been commandeered to serve as hospitals after Prairie Grove, and the printers of Company E obviously planned on recuperating southern soldiers to be among their readership.

The inside pages of the Buck and Ball stand as a further example of a moment frozen in time. In addition to the timely nature of the printed copy, the typesetting is clearer and cleaner than that on the outside pages, evidence of a more deliberate and leisurely effort on the part of the compositors. Although the same mixture of characters from different fonts occurs, they are presented in a bit more orderly fashion than the first im-

${ }^{40}$ OR, Ser. I, Vol. XXII, 97-100.

${ }^{41}$ Buck and Ball, December 6-15, 1862, p. 3. 
pression because the men had ample time while distributing to weed out some of the more unsightly variations.

On December 15, 1862, the Buck and Ball made its appearance at Cane Hill and proved to be a popular diversion for the garrison. Major Plumb proudly exhibited a copy to General Blunt, who was so impressed that he gave the Eleventh Kansas permission to confiscate the printing equipment and pack it along in a wagon when the time came for the regiment to leave the area. Blunt's enthusiasm probably stemmed from his use of a portable press serving his headquarters at Rhea's Mills. ${ }^{42}$ When Brigadier General John Schofield arrived to assume field command of the Army of the Frontier at the end of December, he felt Blunt's headquarters press to be quite enough. Although no written copy of the order has been found, Preston Plumb later insisted that the press at Cane Hill remained behind when his regiment moved out due to a direct command from Schofield to Blunt. ${ }^{43}$

Before Schofield arrived in northwest Arkansas, the printers in Company $\mathrm{E}$ marched south with the rest of Blunt's division to attack Confederate forces lingering at Van Buren. It had been Blunt's intention to move against the enemy much sooner after Prairie Grove, but foul weather had delayed his army until after Christmas. By that time Hindman had withdrawn most of the southern troops to the opposite side of the Arkansas River, and the fight at Van Buren proved to be somewhat low-keyed compared to the conflict at Prairie Grove.

When the Federals returned to Cane Hill on December 31, 1862, another group of printers took possession of the printing office to produce a newspaper. Identifying themselves only as "Kansas Jayhawkers," on the masthead, it is not known if the printers of the Arkansas Traveller were Ross's men or some other talented Kansas soldiers. The paper, dated January 1,1863 , is definitely the product of the same body type as

\footnotetext{
${ }^{42}$ Edmund G. Ross, letter to Fannie Lathrop Ross, December 24, 1862, Edmund G. Ross Collection. This letter is written on a blue sheet of foolscap imprinted with "General Field Orders No. 2, Headquarters, Army of the Frontier, Rhea's Mills, Arkansas, December 12, 1862." The type used in the imprint is a six point Roman face far superior to the eight point mixture used by the printers at Cane Hill. The use of small portable presses by headquarters staffs during the Civil War was not uncommon.

${ }^{43}$ Connelley, Preston B. Plumb, 129; Preston B. Plumb Collection, Scrapbook 3, p. 8.
} 
the Buck and Ball, but the publishers of the Arkansas Traveller managed to find some ornate display characters for the paper's title. Having just come from a town with at least one active press, it is possible the light-fingered Federals raided the office of the Van Buren Press during their visit and carried away enough type for a new masthead.

The Arkansas Traveller dealt entirely with an exchange of letters between Blunt and Hindman debating the issue of truce violations following the battle of Prairie Grove and was printed on only one side of the paper. Since the date of the paper's issuance coincides with the arrival of General Schofield in Arkansas when he assumed field command of the Army of the Frontier, the half-finished document lends credence to Preston Plumb's insistence that the new commander strongly disapproved of regimental publications.

The Eleventh Kansas did not occupy Cane Hill much longer after the dismal debut of the Arkansas Traveller. The lengthy stay in the area by so many troops had exhausted the countryside of forage and the Eleventh moved north, first to Elm Springs, and later to a camp near Springfield, Missouri. The men finally got rid of their hopelessly outdated blunderbusses in August 1863, when the regiment was converted from infantry to cavalry. The Eleventh saw the balance of its Civil War service in Missouri, Kansas, and points west. Whatever became of the printing office they left behind at Cane Hill remains a mystery, but there is, at present, a remote possibility of at least locating the site where the cabin stood. ${ }^{44}$

The story of the fighting printers of Company $\mathrm{E}$ would not be complete without a brief description of their subsequent careers. Of James Conwell and Nathan P. Gregg nothing is known, but John Howard Kitts survived the war and returned to Kansas, establishing a newspaper in Ottawa called the Register. He died at Ottawa in 1870. Henry C. Lindsey, the devil turned drummer boy, attained the rank of captain before

\footnotetext{
${ }^{44}$ Lemke, "Buck and Ball," 29-30. Lemke quotes extensively from an undated account written by James P. Neal describing the discovery of some copies of Buck and Ball in the late nineteenth century within a cabin once used by Andrew Buchanan as a blacksmith's shop. If the cabin Neal described was located at Cane Hill, it could very well be the site of Company E's printing office. To trace the ownership of town lots in Cane Hill owned by Andrew Buchanan would take a dedicated effort, however, since Buchanan was the most common surname among antebellum Cane Hill settlers.
} 
the war's end and spent the rest of his life in and out of Kansas military organizations, eventually becoming a colonel of volunteers in the Spanish-American war. Preston B. Plumb, the Eleventh's major, continued to pursue his political career following Appomattox and was elected United States senator from Kansas in 1877.

Captain Edmund G. Ross lived to return to his wife and children, as he had so earnestly desired. At first he resumed newspaper work, but in 1866 he accepted appointment as United States senator from Kansas from Governor Samuel J. Crawford. He assumed his duties with quiet dignity, and during his tenure in office Ross performed one heroic act which pales his battlefield exploits in comparison.

At the dramatic conclusion of the impeachment trial against President Andrew Johnson, the voting remained split between conviction and aquittal. Edmund Ross, after being subjected to months of intense pressure from constituents and colleagues, was the last senator of the jury to be called. With an intimidating hush presiding over the hall, and the hundreds of spectators eagerly leaning forward to hear him, the Kansas senator spoke the two words which amounted to his own political suicide: "not guilty."

Again the former editor, very much aware that he had made history, reacted to the event by attempting to preserve the moment with his craft. In 1896, while living in New Mexico in a sort of political exile, Edmund Ross stepped up to a typecase with a composing stick, hand-set his version of the impeachment trial, and proceeded to publish the story himself. ${ }^{45}$ The ink still flowed as strongly in the veins of the seventy-one year old printer as it did on that November afternoon so many years before when he spotted the abandoned press at Cane Hill, Arkansas.

\footnotetext{
${ }^{45}$ Robbins, "Edmund G. Ross," 113; Edmund G. Ross, History of the Impeachment Trial of Andrew Johnson (Santa Fe, N. M., 1896).
} 